\title{
PENGGUNAAN KERTAS AKTIF BERBASIS OLEORESIN AMPAS JAHE EMPRIT (Zingiber officinale var. amarum) TERHADAP KUALITAS BUAH STROBERI (Fragaria $x$ ananassa) SELAMA PENYIMPANAN
}

\author{
Sakinah Ummu Zahroh ${ }^{1)}$, Rohula Utami' ${ }^{1)}$, Godras Jati Manuhara ${ }^{1)}$ \\ ${ }^{1)}$ Program Studi Ilmu dan Teknologi Pangan, Fakultas Pertanian, Universitas Sebelas Maret. \\ Email: sakinahummuzahroh@gmail.com
}

\begin{abstract}
Strawberries (Fragaria $x$ ananassa) are one of the horticultural commodities which have a high production and nutritional value. However, strawberries susceptible to loss of quality during postharvest. Changes in the quality of strawberries among others physical, chemical, and microbiological. Therefore, strawberries are required handling during storage with packaging. Active paper packaging based on oleoresin of ginger dreg $2 \%$ containing active substances that inhibit the growth of microbes. This research uses current active paper packaging based on oleoresin ginger dreg as a packaging of strawberries. The purpose of this research was to determine the effect of using active paper packaging based on oleoresin of ginger dreg on the quality of strawberries during 12 days of storage at $10 \pm 2{ }^{\circ} \mathrm{C}$. Results of ANOVA analysis with $5 \%$ significance shows that the use of active paper packaging based on oleoresin ginger dreg effect on weight loss strawberries for 12 days of storage, color of red on the $3 \mathrm{rd}$, 9th, and 12th day of storage, total acid titration on the 12th day of storage, total dissolved solids on 9th and 12th day of storage, and vitamin $C$ on the 12th day of storage. The hardness and $\mathrm{pH}$ value are not affected by the current active paper packaging based on oleoresin ginger dreg during 12 days of storage. Total microbial of strawberries with active paper laying variation has a total microbial lower than strawberries control.
\end{abstract}

Keywords: active paper, ginger dregs, oleoresin, strawberries, quality.

\section{PENDAHULUAN}

Buah stroberi banyak dikonsumsi dalam bentuk segar maupun diolah kembali menjadi produk makanan ${ }^{1}$. Produksi buah stroberi dari tahun 2009-2013 selalu mengalami peningkatan ${ }^{2}$. Kandungan gizi buah stroberi segar tiap 100 gram antara lain energi 37 kalori, protein $0,8 \mathrm{~g}$, lemak $0,5 \mathrm{~g}$, karbohidrat $8,0 \mathrm{~g}$, kalsium $28 \mathrm{mg}$, fosfat $27 \mathrm{mg}$, besi 0,8 $\mathrm{mg}$, vitamin A $60 \mathrm{SI}$, vitamin B $0,03 \mathrm{mg}$, vitamin C $60 \mathrm{mg}$ dan air $89,9 \mathrm{~g}^{3}$ dan bagian yang dapat dimakan $96 \%{ }^{1}$. Buah stroberi mengandung suatu senyawa antioksidan berupa asam ellagic yang merupakan zat fitokemikali yang memiliki daya anti karsinogenik dan anti mutagenik ${ }^{4}$.

Penurunan kualitas buah stroberi tidak diinginkan oleh konsumen. Beberapa perubahan/penurunan kualitas yang terjadi pada buah stroberi antara lain penyusutan massa sejak pemanenan hingga saat dikonsumsi, laju respirasi yang tinggi memicu kerusakan yang cepat, laju transpirasi yang tinggi yang menyebabkan susut bobot, kelayuan, penurunan nilai tekstur dan gizi, serta pencoklatan yang dapat disebabkan oleh enzimatik dan non-enzimatik ${ }^{5}$ Parameter kimia berupa total padatan terlarut dan total asam mempengaruhi rasa serta aroma buah, sedangkan kandungan vitamin $\mathrm{C}$ merupakan atribut gizi yang penting pada buah stroberi ${ }^{6}$. Sedangkan kerusakan mikrobiologis pada buah stroberi disebabkan oleh mikroorganisme terutama kapang dan bakteri ${ }^{7}$.

Salah satu teknologi yang digunakan dalam penanganan pascapanen adalah kemasan aktif. Kemasan ini bersifat interaktif karena adanya interaksi aktif dari bahan kemasan dan bahan pangan yang dikemas ${ }^{8}$. Salah satu kemasan aktif adalah kertas aktif. Kertas memiliki potensi sebagai pengemas aktif karena kertas memiliki struktur berpori, sehingga agen antimikroba yang terserap di pori-pori dapat meningkatkan kinerja bahan kertas, seperti uap air dan permeabilitas gas, kekuatan fisik, sifat optik, dan sifat permukaan, serta aktivitas antimikroba. Agen antimikroba bahan kemasan dapat berdifusi ke produk makanan dan proses migrasi ini dapat memperpanjang masa simpan produk yang dikemas?.

Pada kertas aktif dengan tambahan oleoresin ampas jahe $2 \%$ adalah kertas aktif terbaik dibandingkan kertas aktif dengan 
tambahan oleoresin 0\%, 4\%, dan $6 \%$. Karakteristik kertas aktif terbaik adalah kadar air $9,93 \pm 0,30 \%$; ketebalan $0,81 \pm 0,00 \mathrm{~mm}$; ketahanan tarik $0,54 \pm 0,04 \mathrm{~N} / \mathrm{mm}$; dan ketahanan lipat 0,30 . Hasil uji kesukaan semua parameter menunjukkan panelis dapat menerima kertas aktif tersebut (bersifat netral). Hasil uji FTIR menunjukkan adanya senyawa aktif jahe pada pembuatan oleoresin berupa gingerol dan zingeron ${ }^{10}$. Gingerol bekerja aktif merusak membran luar dan membran sitoplasma dinding sel bakteri ${ }^{11}$. Sedangkan zingeron dapat menghambat pertumbuhan mikroba patogen dan perusak pangan ${ }^{12}$. Tujuan dari penelitian ini adalah untuk mengetahui pengaruh aplikasi kertas aktif berbasis oleoresin ampas jahe terhadap kualitas buah stroberi berupa susut bobot, perubahan warna, kekerasan, nilai $\mathrm{pH}$, total asam tertitrasi, kadar vitamin $\mathrm{C}$, total padatan terlarut, dan total mikroorganisme buah stroberi selama penyimpanan.

\section{METODE PENELITIAN}

\section{Rancangan Penelitian}

Rancangan penelitian menggunakan Rancangan Acak Lengkap (RAL) dengan satu faktor, yaitu peletakkan kertas aktif pada pengemas mika. Lembaran kertas aktif akan diberi perlakuan sebagai alas, alas dan dinding, seluruh permukaan (selubung), dan potongan kecil di sela-sela buah serta kontrol (tanpa kertas aktif). Sampel akan diamati pada hari ke $0,3,6,9$, dan 12 dengan 2 kali ulangan analisis. Data hasil penelitian dianalisa statistik dengan metode One Way ANOVA $(\alpha$ $=0,05)$. Apabila hasil menunjukkan perbedaan antar variabel maka dilanjutkan dengan DMRT $(\alpha=0,05)$.

\section{Bahan dan Alat Utama}

Bahan yang digunakan adalah ampas jahe (CV. Intrafood), etanol $96 \%$ pulp kertas saring (Agung Jaya), chitosan (Lancar Karunia), asam asetat $1 \%$, tween 80 (Bratachem), pati tapioka merk Rose Brand, buah stroberi varietas Kalibret (Ciwidey, Bandung), mika plastik (PET punnet) ukuran $10 \times 7 \times 3 \mathrm{~cm}$, buffer $\mathrm{pH} 4$ dan $7, \mathrm{NaOH} 0,1$ $\mathrm{N}$, indikator fenolftalein, iod $0,01 \mathrm{~N}$, amilum $1 \%$, media PCA, garam fisiologis dan aquades.

Alat yang digunakan adalah alat ekstraksi maserasi, Rotary Evaporator (IKA RV 10 basic), blender (Cosmos CB-285G), hot platestirrer (Heidolph R3001K), magnetic stirer, alat pencetak kertas, showcase (Polytron), neraca analitik (Ohaus Adventurer), Color Analyzer (Lutron RGB-1002), Fruit Hardness Tester (Lutron FR-5105), hand refractometer (ATAGO), pH meter (Hanna-H198103), alat titrasi, alat uji TPC.

\section{Tempat}

Penelitian dilaksanakan di Laboratorium Rekayasa Proses Pengolahan Pangan dan Hasil Pertanian, Laboratorium Mikrobiologi dan Bioteknologi, Laboratorium Kimia Pangan dan Biokimia Fakultas Pertanian Universitas Sebelas Maret, dan Laboratorium Pusat MIPA Sub-Laboratorium Biologi Universitas Sebelas Maret mulai bulan November 2015-April 2016.

\section{Teknik Pengumpulan Data}

1. Ekstraksi Oleoresin

Pengeringan ampas jahe selama 4-5 hari dengan metode kering angin sampai kadar air 12-14\%. Ampas jahe kering digiling dan diayak sehingga diperoleh ukuran lolos 30 mesh dan tertahan 50 mesh. Proses ekstraksi ampas jahe menggukan metode ekstraksi maserasi ${ }^{10}$ yaitu $100 \mathrm{~g}$ bubuk ampas jahe dan pelarut $600 \mathrm{ml}$ etanol 96\% (perbandingan 1:6) diekstraksi selama 2 jam pada suhu ruang (T: $30-32^{\circ} \mathrm{C}$ ) dengan pengadukan $500 \mathrm{rpm}$ diatas hot plate, kemudian dilanjutkan pendiaman hasil ekstraksi selama 12, selanjutnya disaring. Filtrat yang diperoleh kemudian dievap pada suhu $50{ }^{\circ} \mathrm{C}$, tekanan 500-700 mmHg kondisi vakum, kecepatan putaran $100 \mathrm{rpm}$ selama $\pm 1,5$ jam untuk memperoleh oleoresinnya.

2. Pembuatan Kertas Aktif

$15 \mathrm{~g}$ potongan kertas saring $(2 \mathrm{~mm} \times 2$ $\mathrm{mm}$ ) direndam dalam $250 \mathrm{ml}$ aquades selama 24 jam. Kemudian ditambah aquades $250 \mathrm{ml}$, diblender 5 menit. Kemudian ditambahkan pati tapioka sebanyak $30 \%$ dari berat kertas (4,5 gram) yang dilarutkan dalam $50 \mathrm{ml}$ aquades, diblender 5 menit. Kemudian ditambahkan 0,45 gram bubuk kitosan dalam $100 \mathrm{ml}$ asam asetat glasial $1 \%$, diblender 5 menit. Kemudian ditambahkan oleoresin ampas jahe sebanyak $2 \%$ (b/b pulp) dalam $50 \mathrm{ml}$ aquades dan ditambahkan tween-80 sebanyak 3 tetes. Emulsi oleoresin ditambahkan pada adonan kertas, tapioka, kitosan dan diblender 5 menit. Adonan kertas dicetak pada alat pencetak. 
Lembaran kertas basah dikeringkan pada suhu kamar $30-32{ }^{\circ} \mathrm{C}$ selama 48 jam dengan pembalikan kertas setiap 24 jam pengeringan ${ }^{10}$.

3. Aplikasi Kertas Aktif pada Buah Stroberi

Kertas aktif dipotong (luas $213 \pm 1 \mathrm{~cm}^{2}$ ) kemudian di aplikasikan pada kemasan mika dengan lima perlakuan peletakan kertas aktif, yaitu kontrol (tanpa kertas aktif), kertas aktif di alas mika, alas dan dinding, di seluruh permukaan, dan potongan kecil di sela-sela buah. Mika plastik PET punnet dilubangi terlebih dahulu menggunakan perforator kertas dengan diameter lubang $0,6 \mathrm{~cm}$ sebanyak 4 buah dengan jarak antar lubang $1,5 \mathrm{~cm}$. Lubang berada ditengah-tengah tutup mika. Lubang pada mika berfungsi untuk mencegah kondensasi didalam mika ${ }^{13}$. Stroberi sebanyak 6 buah (berat total antara 65-76 gram) dimasukkan dalam kemasan mika kemudian ditutup menggunakan stapler dan disimpan selama 12 hari pada suhu $10 \pm 2{ }^{\circ} \mathrm{C}$.

\section{Teknik Analisis}

1. Uji Susut bobot

Metode gravimetri ${ }^{14}$ yaitu berdasarkan persentase berat bahan sejak awal sampai akhir penyimpanan.

2. Uji Warna

Menggunakan color analyzer PCERGB yang mengukur indikator warna tingkat kemerahan, kehijauan, dan kebiruan. Jika indikator warna yang ditunjukkan display semakin rendah atau menjauhi angka 1023 (nilai kalibrasi) maka warna semakin gelap ${ }^{15}$.

3. Uji Kekerasan

Menggunakan fruit hardness tester dimana penggunaannya alat diletakkan secara vertikal tepat di atas bagian pangkal, tengah, dan ujung buah yang kemudian ditekan hingga mengenai permukaan kulit buah sampai tanda batas. Perubahan skala setelah mengenai permukaan kulit dicatat ${ }^{16}$.

4. $\mathrm{Uji} \mathrm{pH}$

5 gr slurry stroberi ditambahkan $50 \mathrm{ml}$ aquades, dihomogenisasi. Kemudian mengukur dengn mencelupkan $\mathrm{pH}$ meter ke dalam gelas yang berisi sampel pada suhu ruang. $\mathrm{pH}$ meter dikalibrasi terlebih dahulu dengan menggunakan buffer 4 dan 7 sebelum pengukuran ${ }^{17}$.
5. Uji Asam Tertitrasi ${ }^{18}$

$10 \mathrm{~g}$ slurry buah stroberi dimasukkan kedalam labu takar dan ditambahkan aquades $100 \mathrm{ml}$, dihomogenisasi. Kemudian disaring dan filtrat diambil 25 ml. Kemudian dimasukkan kedalam erlenmeyer ditambah 3 tetes indikator pp kemudian dititrasi dengan $\mathrm{NaOH} 0,1 \mathrm{~N}$ sampai berwarna merah jambu.

6. Uji Total Padatan Terlarut

Menggunakan refractometer Atago yaitu meneteskan 1-2 tetes bagian cairan dari buah stroberi yang telah dihancurkan kepada prisma refractometer. Kemudian dilakukan pembacaan nilai total padatan terlarut yang dinyatakan dengan ${ }^{\circ}$ brix ${ }^{19}$.

7. Uji Kadar Vitamin C

$10 \mathrm{~g}$ slurry buah stroberi dimasukkan kedalam labu takar dan ditambahkan aquades $100 \mathrm{ml}$, dihomogenisasi. Kemudian disaring dan filtrat diambil $25 \mathrm{ml}$. Kemudian dimasukkan kedalam erlenmeyer ditambah $1 \mathrm{ml}$ larutan amilum $1 \%$. Kemudian titrasi dengan larutan iodin standar $0,01 \mathrm{~N}$ sampai larutan berwarna biru $^{20}$. Penghitungan dapat dilakukan dengan mengalikan volume larutan iodin yang terpakai dalam proses titrasi dengan $0,88 \mathrm{mg}^{21}$.

8. Uji Total Plate Count (TPC)

$1 \mathrm{~g}$ slurry stroberi ditambahkan $9 \mathrm{ml}$ larutan fisiologis steril, dihomogenisasi sehingga didapat pengenceran $10^{-1}$. Pengenceran $10^{-2}$ dibuat dengan memasukkan $1 \mathrm{ml}$ sampel dari pengenceran $10^{-1} \mathrm{ke}$ dalam $9 \mathrm{ml}$ larutan fisiologis. Dengan cara yang sama dibuat seri pengenceran $10^{-3}, 10^{-4}, 10^{-5}$. Kemudian inokulasi sampel pada media. Sebanyak 1 $\mathrm{ml}$ larutan sampel dimasukkan kedalam cawan petri. Kemudian dituangkan PCA steril suhu sekitar $50{ }^{\circ} \mathrm{C}$ sebanyak $15 \mathrm{ml}$. Suspensi dihomogenisasi. Selanjutnya dibiarkan sampai media padat dan diinkubasi dengan suhu $37{ }^{\circ} \mathrm{C}$ selama 2 hari. Perhitungan dilakukan dengan cara menghitung koloni yang berdiameter 0,5$3,0 \mathrm{~mm}$ dengan jumlah koloni antara 30 $300 \mathrm{CFU} /$ gram $^{22}$.

\section{HASIL DAN PEMBAHASAN}

\section{Susut Bobot}

Penyebab terjadinya peningkatan susut bobot buah selama penyimpanan adalah 
respirasi dan transpirasiyang berkaitan dengan berkurangnya volume atau bobot produk pascapanen $^{23}$. Penyusutan bobot menyebabkan buah mengerut dan layu serta dapat mempercepat pertumbuhan jasad renik pembusuk sehingga bahan yang disimpan menjadi cepat rusak ${ }^{24}$.

Buah stroberi kontrol mengalami susut bobot yang paling tinggi dibandingkan buah stroberi dengan menggunakan pengemas kertas aktif. Sedangkan buah stroberi dengan penggunaan kertas aktif di seluruh permukaan mika mengalami susut bobot yang paling kecil dibandingkan dengan buah stroberi variasi peletakkan kertas aktif alas, alas+dinding, dan sela-sela. Hal tersebut dikarenakan permukaan yang lebih tertutup sehingga kontak dengan oksigen lebih rendah, dan luas kontak zat aktif oleoresin ampas jahe emprit lebih tinggi. Luas permukaan kertas aktif yang lebih besar pada aplikasi kertas aktif menyebabkan penutupan perforasi (lubang) dapat menurunkan keberadaan oksigen dan meningkatkan paparan minyak essensial pada bahan yang disimpan. Berkurangnya kadar oksigen pada headspace kemasan membuat laju respirasi buah stroberi menurun ${ }^{13}$. Hal tersebut membuktikan bahwa luas permukaan kertas yang bersentuhan dengan buah stroberi pada perlakuan kertas aktif oleoresin ampas jahe di seluruh permukaan kemasan mempengaruhi penurunan susut bobot. Oksigen digunakan oleh buah saat proses respirasi dan akan menghasilkan karbondioksida dan air. Keluarnya air pada buah stroberi dan terjadinya pemecahan komponen organik menurunkan bobot buah sehingga presentase susut buah lebih tinggi ${ }^{5}$.

Tabel 1. Susut Bobot Buah Stroberi Dengan Penggunaan Kertas Aktif Berbasis Oleoresin Ampas Jahe Selama Penyimpanan (\%)

\begin{tabular}{cccccc}
\hline \multirow{2}{*}{ Perlakuan } & \multicolumn{5}{c}{ Lama Penyimpanan (hari) } \\
\cline { 2 - 6 } & Hari ke-0 & Hari ke-3 & Hari ke-6 & Hari ke-9 & Hari ke-12 \\
\hline Kontrol & $0.00^{\mathrm{Aa}} \pm 0.00$ & $3.94^{\mathrm{Db}} \pm 0.40$ & $7.61^{\mathrm{Cc}} \pm 0.40$ & $12.43^{\mathrm{Cd}} \pm 0.10$ & $20.51^{\mathrm{Ce}} \pm 0.41$ \\
Alas & $0.00^{\mathrm{Aa}} \pm 0.00$ & $2.76^{\mathrm{Cb}} \pm 0.03$ & $5.918^{\mathrm{ABc}} \pm 0.55$ & $11.23^{\mathrm{Bd}} \pm 0.41$ & $19.97^{\mathrm{BC}} \pm 0.41$ \\
Alas+dinding & $0.00^{\mathrm{Aa}} \pm 0.00$ & $2.80^{\mathrm{Cb}} \pm 0.06$ & $5.83^{\mathrm{ABc}} \pm 0.76$ & $11.44^{\mathrm{Bd}} \pm 0.42$ & $19.10^{\mathrm{Be}} \pm 0.28$ \\
Seluruh & $0.00^{\mathrm{Aa}} \pm 0.00$ & $0.81^{\mathrm{Aa}} \pm 0.38$ & $4.79^{\mathrm{Ab}} \pm 0.39$ & $10.06^{\mathrm{Ac}} \pm 0.06$ & $18.04^{\mathrm{Ad}} \pm 0.57$ \\
Permukaan & $0.00^{\mathrm{Aa}} \pm 0.00$ & $1.69^{\mathrm{Bb}} \pm 0.08$ & $6.81^{\mathrm{BCc}} \pm 0.37$ & $12.48^{\mathrm{Cd}} \pm 0.00$ & $20.03^{\mathrm{BC}} \pm 0.00$ \\
Sela-sela & Keterangan : - Angka yang diikuti huruf superscript yang sama (a, b, c, d, e) pada baris yang samamenunjukkan tidak beda \\
nyata pada taraf signifikansi 5\%. \\
- Angka yang diikuti huruf superscript yang sama (A, B, C, D, E) pada kolom yang sama menunjukkan tidak \\
beda nyata pada taraf signifikansi 5\%.
\end{tabular}

\section{Warna}

Berdasarkan alat color analyzer, nilai indikator warna yang lebih kecil dari nilai kalibrasi warna putih $(<1023)$ menunjukkan warna yang semakin gelap ${ }^{15}$. Berubahnya warna buah disebabkan oleh proses degradasi maupun proses sintesis dari pigmen-pigmen yang terdapat dalam buah ${ }^{21}$. Pada buah stroberi, pigmen yang memberikan warna merah adalah antosianin ${ }^{25}$. Antosianin termasuk golongan senyawa flavonoid yang kestabilannya dipengaruhi oleh beberapa faktor antara lain $\mathrm{pH}$ dan temperatur. Semakin kecil kadar antosianin buah stroberi, semakin tinggi $\mathrm{pH}$-nya ${ }^{26}$. Pada hasil penelitian ini $\mathrm{pH}$ selama penyimpanan berkisar antara 2,16-3,44 yang masih tergolong asam. Sehingga diduga perubahan stabilitas warna antosianin tetap terjadi namun kecil.
Warna merah pada semua sampel semakin menurun selama penyimpanan, artinya terdapat penurunan komponen warna merah pada permukaan buah stroberi menjadi lebih gelap. Penurunan warna merah buah stroberi yang menandakan menjadi lebih gelap selama penyimpanan disebabkan oleh reaksi pencokelatan, penurunan stabilitas antosianin pada stroberi ${ }^{27}$, dan kelembaban yang sangat rendah selama penyimpanan berlangsung ${ }^{28}$. Selama penelitian berlangsung, $\mathrm{RH}$ berkisar antara $65-75 \%$, sedangkan buah stroberi normal disimpan pada RH antara 90-95\%.

Warna hijau pada buah stroberi berdasarkan hasil analisis ANOVA tidak berbeda nyata antara perlakuan dan peletakkan kemasan kertas aktif. Warna hijau buah stroberi disebabkan pigmen klorofil yang mengalami perubahan selama penyimpanan. Perubahan warna klorofil karena 3 hal yaitu peofitinasi, klorofilid, dan oksidasi. Reaksi 
peofitinasi oleh asam merupakan reaksi pembentukan feofitin sehingga berwarna hijau kecokelatan. Reaksi klorofilid reaksi pembentukan klorofilid oleh enzim klorofilase pada suasana asam dan basa yang bekerja menghidrolisis gugus fitol klorofil menjadi klorofilif yang larut air. Reaksi oksidasi merubah warna pada klorofil oleh oksigen dan panas ${ }^{29}$.Warna biru pada buah stroberi selama penyimpanan tidak berbeda signifikan. Warna biru disebabkan oleh pigmen antosianin pada buah stroberi. Antosianin pada suasana basa berwarna biru. Nilai $\mathrm{pH}$ buah stroberi berkisar antara 2,16-3,44 yang tergolong asam dan diduga tetap terjadi perubahan stabilitas warna antosianin, namun kecil sehingga cenderung stabil.

Tabel 2. Warna buah stroberi dengan penggunaan kertas aktif berbasis oleoresin ampas jahe selama penyimpanan (Redness, Green, and Blue)

\begin{tabular}{|c|c|c|c|c|c|c|}
\hline \multirow[t]{2}{*}{ W } & \multirow{2}{*}{ Perlakuan } & \multicolumn{5}{|c|}{ Lama Penyimpanan (hari) } \\
\hline & & Hari ke-0 & Hari ke-3 & Hari ke-6 & Hari ke-9 & Hari ke-12 \\
\hline \multirow[t]{5}{*}{$\mathrm{R}$} & Kontrol & $220^{\mathrm{Ad}} \pm 8$ & $202^{\mathrm{Bc}} \pm 1$ & $185^{\mathrm{Ab}} \pm 4$ & $177^{\mathrm{Bb}} \pm 3$ & $159^{\mathrm{Ca}} \pm 4$ \\
\hline & Alas & $214^{\mathrm{Ac}} \pm 1$ & $181^{\mathrm{Ab}} \pm 7$ & $176^{\mathrm{Ab}} \pm 1$ & $168^{\mathrm{Ab}} \pm 4$ & $131^{\mathrm{Aa}} \pm 5$ \\
\hline & Alas+dinding & $210^{\mathrm{Ac}} \pm 7$ & $183^{\mathrm{Ab}} \pm 0$ & $179^{\mathrm{Ab}} \pm 0$ & $170^{\mathrm{ABb}} \pm 3$ & $136^{\mathrm{ABa}} \pm 2$ \\
\hline & Seluruh Permukaan & $217^{\mathrm{Ac}} \pm 8$ & $195^{\mathrm{Bb}} \pm 0$ & $184^{\mathrm{Ab}} \pm 6$ & $172^{\mathrm{ABb}} \pm 3$ & $138^{\mathrm{ABa}} \pm 4$ \\
\hline & Sela-sela & $222^{\mathrm{Ae}} \pm 1$ & $196^{\mathrm{Bd}} \pm 1$ & $186^{\mathrm{Ac}} \pm 5$ & $176^{\mathrm{Bb}} \pm 3$ & $146^{\mathrm{Ba}} \pm 4$ \\
\hline \multirow[t]{5}{*}{ G } & Kontrol & $81^{\mathrm{Ab}} \pm 11$ & $69^{\mathrm{Aab}} \pm 1$ & $74^{\mathrm{Ab}} \pm 2$ & $80^{\mathrm{Ab}} \pm 4$ & $55^{\mathrm{Aa}} \pm 8$ \\
\hline & Alas & $89^{\mathrm{Ab}} \pm 22$ & $74^{\mathrm{Aab}} \pm 5$ & $75^{\mathrm{Aab}} \pm 8$ & $71^{\mathrm{Aab}} \pm 2$ & $56^{\mathrm{Aa}} \pm 0$ \\
\hline & Alas+dinding & $71^{\mathrm{Aa}} \pm 3$ & $73^{\mathrm{Aa}} \pm 2$ & $84^{\mathrm{Aa}_{ \pm}}+13$ & $86^{\mathrm{Aa}_{2} \pm 21}$ & $61^{\mathrm{Aa}} \pm 6$ \\
\hline & Seluruh Permukaan & $74^{\mathrm{Aa} \pm 7}$ & $67^{\mathrm{Aa}} \pm 1$ & $71^{\mathrm{Aa}} \pm 4$ & $76^{\mathrm{Aa}} \pm 4$ & $69^{\mathrm{Aa}_{ \pm}}$ \\
\hline & Sela-sela & $68^{\mathrm{Aa} \pm 1}$ & $72^{\mathrm{Aa}} \pm 11$ & $70^{\mathrm{Aa}} \pm 10$ & $78^{\mathrm{Aa}} \pm 8$ & $58^{\mathrm{Aa}} \pm 0$ \\
\hline \multirow[t]{5}{*}{ B } & Kontrol & $59^{\mathrm{Aa}} \pm 3$ & $49^{\mathrm{Aa}} \pm 0$ & $58^{\mathrm{ABa}} \pm 2$ & $62^{\mathrm{Aa}} \pm 4$ & $44^{\mathrm{Aa}} \pm 5$ \\
\hline & Alas & $60^{\mathrm{Ab}} \pm 8$ & $51^{\mathrm{Aab}} \pm 3$ & $56^{\mathrm{ABab}} \pm 6$ & $57^{\mathrm{Aab}} \pm 5$ & $46^{\mathrm{Aa}} \pm 1$ \\
\hline & Alas+dinding & $51^{\mathrm{Aa}} \pm 1$ & $52^{\mathrm{Aa} \pm 1}$ & $61^{\mathrm{Ba}} \pm 4$ & $60^{\mathrm{Aa}} \pm 9$ & $49^{\mathrm{Aa}} \pm 4$ \\
\hline & Seluruh Permukaan & $51^{\mathrm{Aa}} \pm 1$ & $46^{\mathrm{Aa}} \pm 5$ & $55^{\mathrm{ABa}} \pm 1$ & $60^{\mathrm{Aa}} \pm 4$ & $50^{\mathrm{Aa}} \pm 14$ \\
\hline & Sela-sela & $51^{\mathrm{Aab}} \pm 3$ & $53^{\mathrm{Aab}} \pm 6$ & $51^{\mathrm{Aab}} \pm 3$ & $63^{\mathrm{Ab}} \pm 10$ & $46^{\mathrm{Aa}} \pm 1$ \\
\hline
\end{tabular}

Keterangan : - Angka yang diikuti huruf superscript yang sama (a, b, c, d, e) pada baris yang sama menunjukkan tidak beda nyata pada taraf signifikansi $5 \%$.

- Angka yang diikuti huruf superscript yang sama (A, B, C, D, E) pada kolom yang sama menunjukkan tidak beda nyata pada taraf signifikansi $5 \%$.

\section{Kekerasan/Firmness}

Kekerasan buah stroberi semua perlakuan yang cenderung seragam yaitu berkisar antara 0,10-0,14 N, meskipun memiliki kecenderungan semakin menurun yang berarti melunak setiap harinya. Tekstur buah-buahan tergantung pada ketegangan, ukuran, bentuk, dan keterikatan sel-sel serta adanya jaringan penunjang dan susunannya. Pelunakan buah disebabkan beberapa proses antara lain perubahan pati menjadi gula sederhana, adanya pelunakan dinding sel ${ }^{30}$.

Kekerasan buah stroberi mengalami kecenderungan penurunan selama penyimpanan. Perubahan tekstur yang terjadi pada buah yaitu dari keras menjadi lunak sebagai akibat terjadinya proses kelayuan akibat respirasi dan transpirasi. Proses kelayuan ini akan diikuti oleh proses pengeriputan. Adanya proses respirasi dan transpirasi menyebabkan buah dan sayur kehilangan air akibat berkurangnya karbon. Jika air di dalam sel berkurang maka sel akan menjadi lunak dan lemas ${ }^{31}$. Kandungan air yang berkurang mengakibatkan penurunan tekanan turgor sehingga membuat nilai kekerasan pada buah turun ${ }^{14}$. Buah stroberi yang lunak selama penyimpanan terjadi karena terdapat enzim poligalakturonase yang dapat melarutkan dan mendegraasi dinding sel buah $^{32}$.

Secara umum, kekerasan buah stroberi baik kontrol maupun dengan pengemas kertas aktif mengalami penurunan. Penurunan kekerasan buah disebabkan hemiselulosa dan protopektin terdegradasi. Protopektin menurun jumlahnya karena berubah menjadi pektin yang bersifat larut dalam air $^{33}$ oleh enzim protopektinase sehingga menyebabkan sel-sel yang satu dengan lain terlepas dan buah menjadi lunak, kemudian enzim pektinase mengubah pektin menjadi asam pektat ${ }^{34}$. 
Penggunaan Kertas Aktif Berbasis Oleoresin Ampas Jahe Emprit ... Zahroh et al.

Tabel 3. Kekerasan buah stroberi dengan penggunaan kertas aktif berbasis oleoresin ampas jahe selama penyimpanan $(\mathrm{N})$

\begin{tabular}{cccccc}
\hline \multirow{2}{*}{ Perlakuan } & \multicolumn{5}{c}{ Lama Penyimpanan (hari) } \\
\cline { 2 - 6 } & Hari ke-0 & Hari ke-3 & Hari ke-6 & Hari ke-9 & Hari ke-12 \\
\hline Kontrol & $0.12^{\mathrm{Aab}} \pm 0.00$ & $0.12^{\mathrm{Ab}} \pm 0.01$ & $0.11^{\mathrm{ABab}} \pm 0.00$ & $0.11^{\mathrm{Aab}} \pm 0.00$ & $0.10^{\mathrm{Aa}} \pm 0.02$ \\
Alas & $0.12^{\mathrm{Aa}} \pm 0.00$ & $0.11^{\mathrm{Aa}} \pm 0.00$ & $0.11^{\mathrm{Aa}} \pm 0.00$ & $0.11^{\mathrm{Aa}} \pm 0.02$ & $0.11^{\mathrm{Aa}} \pm 0.00$ \\
Alas+dinding & $0.12^{\mathrm{Aa}} \pm 0.01$ & $0.12^{\mathrm{Aa}} \pm 0.003$ & $0.11^{\mathrm{ABa}} \pm 0.01$ & $0.12^{\mathrm{Aa}} \pm 0.001$ & $0.11^{\mathrm{Aa}} \pm 0.004$ \\
Seluruh & $0.12^{\mathrm{Aa}} \pm 0.00$ & $0.15^{\mathrm{Aa}} \pm 0.00$ & $0.11^{\mathrm{Aa}} \pm 0.00$ & $0.11^{\mathrm{Aa}} \pm 0.04$ & $0.12^{\mathrm{Aa}} \pm 0.00$ \\
Permukaan & $0.12^{\mathrm{Aa}} \pm 0.00$ & $0.13^{\mathrm{Aa}} \pm 0.02$ & $0.13^{\mathrm{Ba}} \pm 0.01$ & $0.13^{\mathrm{Aa}} \pm 0.03$ & $0.12^{\mathrm{Aa}} \pm 0.01$ \\
Sela-sela & &
\end{tabular}

Keterangan : - Angka yang diikuti huruf superscript yang sama (a, b, c, d, e) pada baris yang samamenunjukkan tidak beda nyata pada taraf signifikansi $5 \%$.

- Angka yang diikuti huruf superscript yang sama (A, B, C, D, E) pada kolom yang sama menunjukkan tidak beda nyata pada taraf signifikansi $5 \%$.

pH

$\mathrm{pH}$ berhubungan dengan kandungan asam organik yang terdapat pada buah. $\mathrm{pH}$ dan total asam memiliki hubungan yang berkebalikan dimana nilai $\mathrm{pH}$ yang lebih tinggi menunjukkan penurunan tingkat keasaman buah $^{35}$. pH yang semakin meningkat menyatakan bahwa turunnya kandungan asam disebabkan oleh berkurangnya sintesis asam yang digunakan sebagai sumber energi dalam proses perkembangan buah $^{36}$. Buah stroberi mengandung asam-asam organik meliputi asam sitrat, malat, siklamat, susinat, gliserat, glikolat, dan aspertat. Penyimpanan buah yang semakin lama menyebaban total asam buah semakin menurun karena digunakan sebagai energi pada proses respirasi sehingga total asam akan berkurang seiring dengan lama penyimpanan $^{37}$.

Tabel 4. $\mathrm{pH}$ buah stroberi dengan penggunaan kertas aktif berbasis oleoresin ampas jahe selama penyimpanan

\begin{tabular}{clllll}
\hline \multirow{2}{*}{ Perlakuan } & \multicolumn{5}{c}{ Lama Penyimpanan (hari) } \\
\cline { 2 - 6 } & \multicolumn{1}{c}{ Hari ke-0 } & \multicolumn{1}{c}{ Hari ke-3 } & \multicolumn{1}{c}{ Hari ke-6 } & Hari ke-9 & Hari ke-12 \\
\hline Kontrol & $2,20^{\mathrm{ABa}} \pm 0,02$ & $2,52^{\mathrm{ABb}} \pm 0,01$ & $2,86^{\mathrm{Ac}} \pm 0,10$ & $2,90^{\mathrm{Ac}} \pm 0,00$ & $3,38^{\mathrm{Ad}} \pm 0,07$ \\
Alas & $2,16^{\mathrm{Aa}} \pm 0,02$ & $2,52^{\mathrm{ABb}} \pm 0,04$ & $2,95^{\mathrm{Ac}_{0}} \pm 0,02$ & $2,87^{\mathrm{Ac}} \pm 0,07$ & $3,30^{\mathrm{Ad}} \pm 0,18$ \\
Alas+dinding & $2,26^{\mathrm{BC}} \pm 0,06$ & $2,58^{\mathrm{Bb}} \pm 0,02$ & $2,94^{\mathrm{Ac}} \pm 0,004$ & $2,85^{\mathrm{Ac}} \pm 0,07$ & $3,35^{\mathrm{Ad}} \pm 0,01$ \\
Seluruh Permukaan & $2.29^{\mathrm{BCa}} \pm 0,04$ & $2.53^{\mathrm{ABb}} \pm 0,03$ & $2.92^{\mathrm{Ac}} \pm 0,04$ & $2.91^{\mathrm{Ac}} \pm 0,03$ & $3,44^{\mathrm{Ad}} \pm 0,02$ \\
Sela-sela & $2.35^{\mathrm{Ca}} \pm 0,01$ & $2.51^{\mathrm{Ab}} \pm 0,01$ & $3.03^{\mathrm{Ac}} \pm 0,11$ & $2.95^{\mathrm{Ac}} \pm 0,00$ & $3.32^{\mathrm{Ad}} \pm 0,04$ \\
\hline
\end{tabular}

Keterangan : - Angka yang diikuti huruf superscript yang sama (a, b, c, d, e) pada baris yang samamenunjukkan tidak beda nyata pada taraf signifikansi $5 \%$.

- Angka yang diikuti huruf superscript yang sama (A, B, C, D, E) pada kolom yang sama menunjukkan tidak beda nyata pada taraf signifikansi $5 \%$.

\section{Total Asam Tertitrasi}

Perubahan total asam tertitrasi disebabkan oleh adanya perubahan kandungan asam-asam organik yang terkandung di dalam produk $^{38}$. Perubahan total asam tertitrasi dapat dipengaruhi oleh lama penyimpanan, reaksi enzimatik dan perubahan mikrobiologis ${ }^{39}$. Semakin tinggi total asam tertitrasi akan menyebabkan semakin tingginya derajat keasaman buah yang ditandai dengan semakin rendahnya $\mathrm{pH}^{38}$.

Buah stroberi secara umum mengalami penurunan total asam tertitrasi selama penyimpanan. Kandungan asam organik buah menurun selama proses penyimpanan karena direspirasikan atau diubah menjadi gula sederhana ${ }^{37}$. Pada proses respirasi, selain gula, asam organik juga dapat dioksidasi, sehingga bila laju respirasi suatu produk tinggi maka laju pengurangan asam organiknya juga semakin cepat ${ }^{40}$. Selama penyimpanan, terjadi penurunan kadar total asam tertitrasi. Diduga tingginya respirasi selama penyimpnan mempengaruhi kadar total asam tertitrasi pada buah $^{41}$. 
Tabel 5. Total asam tertitrasi buah stroberi dengan penggunaan kertas aktif berbasis oleoresin ampas jahe selama penyimpanan (\%)

\begin{tabular}{ccllll}
\hline \multirow{2}{*}{ Perlakuan } & \multicolumn{5}{c}{ Lama Penyimpanan (hari) } \\
\cline { 2 - 6 } & \multicolumn{1}{c}{ Hari ke-0 } & \multicolumn{1}{c}{ Hari ke-3 } & Hari ke-6 & Hari ke-9 & Hari ke-12 \\
\hline Kontrol & $4.50^{\mathrm{Ad}} \pm 0.00$ & $4.04^{\mathrm{ABc}} \pm 0.00$ & $3.88^{\mathrm{Ac}} \pm 0.00$ & $3.54^{\mathrm{Ab}} \pm 0.14$ & $3.20^{\mathrm{Aa}} \pm 0.00$ \\
Alas & $4.60^{\mathrm{Ac}} \pm 0.00$ & $3.74^{\mathrm{Ab}} \pm 0.20$ & $3.56^{\mathrm{Aab}} \pm 0.17$ & $3.54^{\mathrm{Aab}} \pm 0.14$ & $3.44^{\mathrm{ABa}} \pm 0.00$ \\
Alas+dinding & $4.16^{\mathrm{Ab}} \pm 0.00$ & $4.00^{\mathrm{ABa}} \pm 0.00$ & $3.76^{\mathrm{Aa}} \pm 0.00$ & $3.72^{\mathrm{Aa}} \pm 0.00$ & $3.68^{\mathrm{Ba}} \pm 0.00$ \\
Seluruh Permukaan & $4.70^{\mathrm{Aa}} \pm 0.85$ & $4.58^{\mathrm{ABa}} \pm 0.76$ & $4.00^{\mathrm{Aa}} \pm 0.57$ & $3.92^{\mathrm{Aa}} \pm 0.57$ & $3.30^{\mathrm{Aa}} \pm 0.08$ \\
Sela-sela & $5.04^{\mathrm{Ac}} \pm 0.00$ & $4.80^{\mathrm{Bc}} \pm 0.00$ & $4.12^{\mathrm{Ab}} \pm 0.00$ & $3.84^{\mathrm{Aab}} \pm 0.00$ & $3.64^{\mathrm{Ba}} \pm 0.00$ \\
\hline
\end{tabular}

Keterangan : - Angka yang diikuti huruf superscript yang sama (a, b, c, d, e) pada baris yang samamenunjukkan tidak beda nyata pada taraf signifikansi $5 \%$.

- Angka yang diikuti huruf superscript yang sama (A, B, C, D, E) pada kolom yang sama menunjukkan tidak beda nyata pada taraf signifikansi $5 \%$.

Luas kontak yang tinggi menyebabkan zat aktif oleoresin yang terdapat pada kertas aktif lebih banyak keluar sehingga mempengaruhi laju respirasi buah stroberi. Kadar oksigen pada headspace kemasan yang lebih rendah membuat laju respirasi buah stroberi menurun $^{13}$. Selain itu, pada perlakuan peletakkan kertas aktif di alas+dinding dan sela-sela memiliki lubang perforasi yang terbuka sehingga suhu di dalam kemasan lebih dingin. Suhu dingin menyebabkan proses respirasi berjalan lebih lambat sehingga perombakan asam-asam organik pada buah stroberi menjadi lebih lambat ${ }^{42}$. Perlakuan penggunaan kertas aktif di alas+dinding dan sela-sela berpengaruh pada total asam tertirtasi buah stroberi pada hari ke-12.

\section{Total Padatan Terlarut}

Kenaikan total padatan terlarut di awal penyimpanan selama penelitian tidak signifikan sedangkan penurunan total padatan terlarut di akhir penyimpanan signifikan. Penurunan total padatan terlarut menandakan terjadinya penurunan kadar gula dalam buah. Hal ini diduga disebabkan adanya proses respirasi. Karbohidrat menjadi substrat utama yang dipecah menjadi unit-unit gula yang lebih sederhana. Semakin lama penyimpanan maka semakin banyak karbohidrat yang didegradasi karena kesempatan untuk mendegradasi karbohidrat menjadi senyawa organik semakin besar ${ }^{22}$. Selama penyimpanan substrat yang dihidrolisis semakin menurun, dan akhirnya mengakibatkan penurunan total padatan terlarut ${ }^{43}$.

Secara umum, semua buah stroberi baik kontrol maupun dengan pengemas kertas aktif mengalami peningkatan total padatan terlarut pada awal penyimpanan (hari ke-0 sampai 9) kemudian mengalami penuruan yang sangat drastis pada hari ke-12. Namun, peningkatan yang terjadi pada hari ke-0 sampai ke-9 tidak signifikan berdasarkan statistik hal ini karena buah stroberi merupakan buah non-klimaterik dimana total padatan terlarutnya cenderung menurun selama penyimpanan ${ }^{44}$. Kenaikan total padatan terlarut karena sedang terjadi degradasi pati menjadi gula. Selama masa penyimpanan baik kondisi normal maupun dengan perlakuan, total padatan terlarut dipastikan akan mengalami peningkatan ${ }^{45}$. Saat kandungan pati menurun maka kandungan sukrosa akan naik, dan sukrosa yang terbentuk akan dipecah lagi menjadi fruktosa dan glukosa. Glukosa yang terbentuk akan digunakan sebagian untuk proses respirasi ${ }^{46}$.

Total padatan terlarut tertinggi terdapat pada sampel dengan peletakkan kertas aktif pada alas pada hari ke-12. Hal ini diduga karena zat aktif berupa gingerol dan zingeron dari ampas jahe pada kertas aktif yang bersifat hidrofobik dapat memperlambat proses respirasi dan konversi gula pada buah stroberi $^{47}$. Selain itu, pada perlakuan peletakkan kertas aktif di alas memiliki lubang pada bagian atas mika yang tidak terhalang sehingga memudahkan untuk masuknya udara dingin dari showcase ke dalam pengemas mika. Udara dingin menyebabkan proses respirasi berjalan lebih lambat sehingga perombakan pati menjadi karbohidrat yang lebih sederhana pada buah stroberi menjadi lebih lambat ${ }^{42}$. Perlakuan penggunaan kertas aktif di alas berpengaruh pada total padatan terlarut buah stroberi pada hari ke-12. Pada penelitian ini digunakan suhu yang lebih tinggi namun dengan RH yang lebih rendah sehingga hal tersebut mempengaruhi proses respirasi dari buah stroberi yang berhubungan dengan hidrolisis pati menjadi gula reduksi. 
Tabel 6 Total padatan terlarut buah stroberi dengan penggunaan kertas aktif berbasis oleoresin ampas jahe selama penyimpanan $\left({ }^{\circ}\right.$ Brix $)$

\begin{tabular}{cccccc}
\hline \multirow{2}{*}{ Perlakuan } & \multicolumn{5}{c}{ Lama Penyimpanan (hari) } \\
\cline { 2 - 6 } & Hari ke-0 & Hari ke-3 & Hari ke-6 & Hari ke-9 & Hari ke-12 \\
\hline Kontrol & $4.8^{\mathrm{Ab}} \pm 0.0$ & $5.1^{\mathrm{Ab}} \pm 0.1$ & $5.3^{\mathrm{Ab}} \pm 0.4$ & $5.1^{\mathrm{Ab}} \pm 0.1$ & $3.6^{\mathrm{Ba}} \pm 0.0$ \\
Alas & $5.0^{\mathrm{Aab}} \pm 0.4$ & $5.0^{\mathrm{Aab}} \pm 0.0$ & $5.2^{\mathrm{Ab}} \pm 0.0$ & $5.4^{\mathrm{Bb}} \pm 0.0$ & $4.6^{\mathrm{Da}} \pm 0.3$ \\
Alas+dinding & $5.1^{\mathrm{Aab}} \pm 0,1$ & $5.0^{\mathrm{Aab}} \pm 0.0$ & $5.2^{\mathrm{Aab}} \pm 0.0$ & $5.7^{\mathrm{Cb}} \pm 0.1$ & $4.2^{\mathrm{Ca}} \pm 0.0$ \\
Seluruh Permukaan & $4.9^{\mathrm{Ab}} \pm 0.2$ & $4.8^{\mathrm{Ab}} \pm 0.0$ & $4.8^{\mathrm{Ab}} \pm 0.0$ & $5.0^{\mathrm{Ab}} \pm 0.0$ & $3.2^{\mathrm{Aa}} \pm 0.0$ \\
Sela-sela & $4.8^{\mathrm{Aa}} \pm 0.0$ & $5.0^{\mathrm{Aa}} \pm 0.0$ & $5.0^{\mathrm{Aa}} \pm 0.0$ & $5.4^{\mathrm{Ba}} \pm 0.0$ & $4.0^{\mathrm{Ca}} \pm 0.0$ \\
\hline
\end{tabular}

Keterangan : - Angka yang diikuti huruf superscript yang sama (a, b, c, d, e) pada baris yang samamenunjukkan tidak beda nyata pada taraf signifikansi $5 \%$.

- Angka yang diikuti huruf superscript yang sama (A, B, C, D, E) pada kolom yang sama menunjukkan tidak beda nyata pada taraf signifikansi $5 \%$.

\section{Kadar Vitamin C}

Pada hasil uji vitamin $\mathrm{C}$ hari ke-12 buah stroberi terdapat perbedaan yang signifikan antara buah stroberi kontrol dengan perlakuan alas dan sela-sela. Perbedaan tersebut juga didukung dengan penurunan kadar vitamin $\mathrm{C}$ buah stroberi selama penyimpanan. Pada
Tabel 8 tentang penurunan kadar vitamin $\mathrm{C}$ buah stroberi selama penyimpanan, dapat dilihat bahwa buah stroberi dengan perlakuan sela-sela memiliki penurunan kadar vitamin $\mathrm{C}$ yang paling kecil pada hari ke-3, 6, dan 12 penyimpanan.

Tabel 7. Kadar vitamin $\mathrm{C}$ buah stroberi dengan penggunaan kertas aktif oleoresin ampas jahe selama penyimpanan $(\mathrm{mg} / 100 \mathrm{~g})$

\begin{tabular}{|c|c|c|c|c|c|}
\hline \multirow{2}{*}{ Perlakuan } & \multicolumn{5}{|c|}{ Lama Penyimpanan (hari) } \\
\hline & Hari ke-0 & Hari ke-3 & Hari ke-6 & Hari ke-9 & Hari ke-12 \\
\hline Kontrol & $25.08^{\mathrm{Ac}} \pm 0.00$ & $23.76^{\mathrm{Ac}} \pm 0.00$ & $20.46^{\mathrm{Ab}} \pm 2.18$ & $19.58^{\mathrm{Ab}} \pm 0.31$ & $11.44^{\mathrm{Aa}} \pm 0.00$ \\
\hline Alas & $24.20^{\mathrm{Ab}} \pm 3.73$ & $23.10^{\mathrm{Ab}} \pm 0.31$ & $21.34^{\mathrm{Ab}} \pm 0.93$ & $19.36^{\mathrm{Ab}} \pm 1.87$ & $12.54^{\mathrm{Ba}} \pm 0.69$ \\
\hline Alas+dinding & $24.42^{\mathrm{Ac}} \pm 0.93$ & $23.76^{\mathrm{Ac}} \pm 0.00$ & $20.24^{\mathrm{Ab}} \pm 0.62$ & $21.12^{\mathrm{Ab}} \pm 0.00$ & $11.88^{\mathrm{ABa}} \pm 0.00$ \\
\hline $\begin{array}{c}\text { Seluruh } \\
\text { Permukaan }\end{array}$ & $25.30^{\mathrm{Ad}} \pm 0.31$ & $24.2^{\mathrm{Ac}} \pm 0.00$ & $20.90^{\mathrm{Ab}} \pm 0.31$ & $20.68^{\mathrm{Ab}} \pm 0.00$ & $11.88^{\mathrm{ABa}} \pm 0.00$ \\
\hline Sela-sela & $24.20^{\mathrm{Ac}} \pm 1.87$ & $23.32^{\mathrm{Ac}} \pm 1.87$ & $21.56^{\mathrm{Abc}} \pm 0.62$ & $18.92^{\mathrm{Ab}} \pm 0.62$ & $13.64^{\mathrm{Ca}} \pm 0.00$ \\
\hline
\end{tabular}

Tabel 8. Penurunan kadar vitamin $\mathrm{C}$ buah stroberi dengan penggunaan kertas aktif berbasis oleoresin ampas jahe selama penyimpanan (\%)

\begin{tabular}{cccccc}
\hline \multirow{2}{*}{ Perlakuan } & \multicolumn{5}{c}{ Lama Penyimpanan (hari) } \\
\cline { 2 - 6 } & Hari ke-0 & Hari ke-3 & Hari ke-6 & Hari ke-9 & Hari ke-12 \\
\hline Kontrol & 0 & 5.26 & 18.42 & 21.93 & 54.39 \\
Alas & 0 & 4.55 & 11.81 & 20.00 & 48.18 \\
Alas+dinding & 0 & 2.70 & 17.12 & 13.51 & 51.35 \\
Seluruh Permukaan & 0 & 4.35 & 17.39 & 18.26 & 53.04 \\
Sela-sela & 0 & 3.64 & 10.91 & 21.82 & 43,64 \\
\hline
\end{tabular}

Kerusakan vitamin C pada buah stroberi dapat terjadi karena adanya proses oksidasi vitamin $\mathrm{C}^{48}$ dan berhubungan dengan aktivitas ascorbic acid oxidase yang terdapat dalam jumlah lebih tinggi pada buah ${ }^{49}$. Pada sampel buah stroberi perlakuan sela-sela memiliki penurunan kadar vitamin $\mathrm{C}$ yang paling rendah. Hal ini dikarenakan dengan adanya pemotongan ukuran kertas semakin memudahkan zat aktif yang terdapat pada kertas aktif transfer ke dalam headspace kemasan, sehingga headspace kemasan terisi dengan zat aktif yang membuat kadar oksigen berkurang. Berkurangnya kadar oksigen di dalam kemasan membuat proses oksidasi buah stroberi menurun sehingga kerusakan vitamin $\mathrm{C}$ juga menurun. 


\section{Total Mikroba}

Bila dilihat secara umum buah stroberi dengan perlakuan pengemas kertas aktif oleoresin ampas jahe memiliki total mikroba yang lebih rendah dibandingkan dengan buah stroberi kontrol. Hal ini terjadi karena zat aktif yang terdapat pada kertas aktif oleoresin ampas jahe mampu menghambat pertumbuhan mikroba pada buah stroberi. Penghambatan mikroba tersebut berasal dari gugus aktif pada gingerol, zingeron, dan kitosan asetat ${ }^{10}$.

Kitosan bersifat antibakteri karena mengandung struktur polimer yang mempunyai gugus amin bermuatan positif, sedangkan polisakarida lain umumnya bersifat netral atau bermuatan negatif. Gugus amin kitosan tersebut dapat berinteraksi dengan muatan negatif suatu molekul seperti protein dari mikroba yang menyebabkan bocornya protein dan struktur intraseluler dari mikroba $^{50}$.

Tabel 9. Total mikroba buah stroberi dengan penggunaan kertas aktif berbasis oleoresin ampas jahe selama penyimpanan $(\log \mathrm{CFU} / \mathrm{ml})$

\begin{tabular}{clllll}
\hline \multirow{2}{*}{ Perlakuan } & \multicolumn{5}{c}{ Lama Penyimpanan (hari) } \\
\cline { 2 - 6 } & \multicolumn{1}{c}{ Hari ke-0 } & Hari ke-3 & \multicolumn{1}{c}{ Hari ke-6 } & Hari ke-9 & Hari ke-12 \\
\hline Kontrol & $3.40^{\mathrm{Aa}} \pm 0.004$ & $4.11^{\mathrm{Aab}} \pm 0.06$ & $4.02^{\mathrm{Aab}} \pm 1.36$ & $5.32^{\mathrm{Aab}} \pm 1.40$ & $6.28^{\mathrm{ABb}} \pm 0.27$ \\
Alas & $3.22^{\mathrm{Aa}} \pm 0.06$ & $3.39^{\mathrm{Aa}} \pm 0.12$ & $4.06^{\mathrm{Ab}} \pm 0.20$ & $4.60^{\mathrm{Ac}} \pm 0.13$ & $5.15^{\mathrm{Ad}} \pm 0.15$ \\
Alas+dinding & $2.92^{\mathrm{Aa}} \pm 0.02$ & $3.69^{\mathrm{Aab}} \pm 0.56$ & $4.40^{\mathrm{Aabc}} \pm 0.2$ & $5.14^{\mathrm{Abc}} \pm 1.32$ & $5.96^{\mathrm{Ac}} \pm 0.00$ \\
Seluruh Permukaan & $2.84^{\mathrm{Aa}} \pm 0.06$ & $3.76^{\mathrm{Aab}} \pm 0.19$ & $4.36^{\mathrm{Abc}} \pm 0.11$ & $5.02^{\mathrm{Acd}} \pm 0.10$ & $5.86^{\mathrm{Ad}} \pm 0.89$ \\
Sela-sela & $2.83^{\mathrm{Aa}} \pm 0.47$ & $3.25^{\mathrm{Aab}} \pm 0.00$ & $3.49^{\mathrm{Aab}} \pm 1.30$ & $3.82^{\mathrm{Aab}} \pm 1.83$ & $5.97^{\mathrm{Ab}} \pm 0.01$ \\
\hline
\end{tabular}

Keterangan : - Angka yang diikuti huruf superscript yang sama (a, b, c, d, e) pada baris yang samamenunjukkan tidak beda nyata pada taraf signifikansi $5 \%$.

- Angka yang diikuti huruf superscript yang sama (A, B, C, D, E) pada kolom yang sama menunjukkan tidak beda nyata pada taraf signifikansi $5 \%$.

Senyawa antimikroba bekerja spesifik, sehingga bahan pangan yang mengandung penghambat masih tetap dapat rusak oleh mikroorganisme yang tahan terhadap antimikroba tersebut ${ }^{53}$. Total mikroba buah stroberi antar variasi peletakkan kertas aktif tidak saling berbeda nyata. Hal ini disebabkan karena gingerol dan zingeron lebih mampu menghambat pertumbuhan bakteri tertentu seperti bakteri Micrococcus varians, Leuconostoc sp, Bacillus substillis, dan Enterobacter arogenes ${ }^{54}, \quad$ Salmonella tyhimurium, Candida albicans ${ }^{55}$, Bacillus cereus (bakteri Gram positif pembentuk spora), dan Escherichia coli, Salmonella typhimurium, dan Pseudomonas aeruginosa (bakteri Gram negatif) ${ }^{56}$. Sedangkan mikroba yang biasanya tumbuh pada buah stroberi adalah Rhizopus stolonifer ${ }^{67}$, Colletotrichum
Gingerol dan zingeron merupakan turunan fenol ${ }^{51}$. Fenol menyerang mikrobanya dengan cara bereaksi dengan membran sel dengan cara merusak permeabilitas membran sel. Kerusakan membran sel dapat menyebabkan kebocoran sehingga komponenasam nukleat, dan lain-lain dapat keluar. Hal ini menyebabkan permeabilitas sel terganggu sehingga sel tidak dapat melakukan aktivitas hidup dan pertumbuhannya terhambat atau bahkan mati ${ }^{52}$. Fenol konsentrasi tinggi dapat merusak sel mikroorganisme dengan cara menyebabkan koagulasi protein serta menyebabkan kebocoran membran dan dinding sel, sedangkan fenol pada konsentrasi rendah akan menyebabkan inaktivasi enzimenzim yang penting dalam metabolisme sel mikroorganisme $^{22}$. komponen penting di dalam sel seperti protein, 
$\log \mathrm{CFU} / \mathrm{ml}$. Hal ini menunjukkan bahwa terdapat perbedaan hasil total mikroba antara buah stroberi dengan dan tanpa penggunaan kertas aktif setelah penyimpanan 12 hari.

\section{KESIMPULAN}

Penggunaan kertas aktif oleoresin ampas jahe emprit berpengaruh signifikan terhadap susut bobot buah stroberi selama 12 hari penyimpanan, warna pada hari ke-3, 9, dan 12, total asam pada hari ke-12, total padatan terlarut pada hari ke-9 dan 12, dan vitamin C pada hari ke-12. Pengguaan kertas aktif oleoresin ampas jahe tidak berpengaruh signifikan pada nilai kekerasan dan $\mathrm{pH}$ buah stroberi selama 12 hari penyimpanan. Penggunaan kertas aktif oleoresin ampas jahe terhadap total mikroba pada buah stroberi dengan variasi perlakuan tidak berbeda siginifikan selama penyimpanan 12 hari.

\section{DAFTAR PUSTAKA}

${ }^{1]}$ Rukmana, Rahmat. 1998. Stroberi, Budi Daya dan Pasca Panen. Kanisius. Yogyakarta.

${ }^{2]}$ Bahar, Yul Harry. 2014. Statistik Produksi Hortikultura Tahun 2013. Dirjen Hortikultura. Jakarta.

${ }^{3]}$ Budiman, S., dan D. Saraswati, 2008. Berkebun Stroberi Secara Komersial. Penebar Swadaya. Jakarta.

${ }^{4]}$ Hannum, S. M. 2004. Potential impact of strawberry on human health: a review of the science. Cnt. Rev. Food Science Nutrition 44(1): 1-17.

${ }^{5]}$ Harianingsih. 2010. Pemanfaatan limbah cangkang kepiting menjadi kitosan sebagai bahan pelapis (coater) pada buah stroberi. Tesis. Universitas Diponegoro.

${ }^{6]}$ Maghfoer, Moch. Dawam, YB. Suwasono Heddy, dan Aldilla Putri Rahayu. 2010. Aplikasi $\mathrm{CaCl}_{2}$ dalam upaya memperpanjang daya simpan buah stroberi (Fragaria ananassa) pada umur panen Berbeda. Pros. SemNas Hortikultura. Universitas Udayana.

${ }^{7]}$ Rahayu, Winiati P. dan C. C. Nurwiti. 2012. Mikrobiologi Pangan. IPB Press. Bogor.
${ }^{8]}$ Julianti, E. dan M. Nurminah. 2006. Buku Ajar Teknologi Pengemasan. Dep. Tek. Pert. Fakultas Pertanian. USU Medan.

${ }^{9}$ Rakchoy, S., P. Suppakul, dan T. Jiankam. 2009. Antimicrobial effects of vanillin coated solution for coating paperboard intended for packaging bakery products. As. J. Food Ag-Ind 2(4): 139.

${ }^{10]}$ Wiastuti, Tri, L. U. Khasanah, Kawiji, W. Atmaka, G. J. Manuhara dan R. Utami. 2016. Characterization of active paper packaging incorporated with ginger pulp oleoresin. IOP Conference Series: Materials Science and Engineering 107:18.

${ }^{11}$ Fathona D. 2011. Kandungan Gingerol Dan Shogaol, Intensitas Kepedasan Dan Penerimaan Panelis Terhadao Oleoresin Jahe Gajah (Zingiber officinale Var Roscoe), Jahe Emprit (Zingiber officinale Var. Amarum), Dan Jahe Merah (Zingiber officinale Var. Rubrum).IPB. Bogor.

${ }^{12}$ Nursal, Wulandari, dan S., Juwita, WS. 2006. Bioaktivitas ekstrak jahe (Zingiber officinale) dalam menghambat pertumbuhan koloni bakteri eschericia coli dan bacillus subtilis. J. Biogenesis 2(2): 64-66.

${ }^{13]}$ Echegoyen, Y, dan C. Nerín. 2015. Performance of an active paper based on cinnamon essential oil in mushrooms quality. Food Chemistry 170: 30-36.

${ }^{14]}$ Nasution I. S., Yusmanizar, dan K. Melianda. 2012. Pengaruh penggunaan lapisan edibel (edible coating), kalsium klorida, dan kemasan plastik terhadap mutu nanas (Ananas cosmosus Merr.) terolah minimal. J. Tek. dan Industri Pert. Indonesia 4(2): 21-27.

${ }^{15]}$ Agustiningrum, D A, Bambang S, Rini Y. 2014. Studi pengaruh konsentrasi oksigen pada penyimpanan atmosfer termodifikasi buah sawo (Achras zapota L). J. Bioproses Komoditas Tropis 2(1): 22-34.

${ }^{16]}$ Syafutri M I, Pratama F, dan Saputra D. 2006. Sifat fisik dan kimia buah mangga (Mangifera indica L) selama penyimpanan dengan berbagai metode pengemasan. J. Teknologi dan Industri Pangan 17(1):1-11. 
${ }^{17]}$ An, D.S., Park, E., Lee, D.S., 2009. Effect of hypobaric packaging on respiration and quality of strawberry and curled lettuce. Postharvest Biol. Technol. 52, 78-83.

${ }^{19]}$ Tanada-Palmu, P.S., Grosso, C.R.F. 2005. Effect of edible wheat gluten-based films and coatings on refrigerated strawberry (Fragaria Ananassa) quality. Postharvest Biol. Technol. 36, 199-208.

${ }^{20]}$ Sapei, Lanny dan Lie Hwa. 2014. Study on the kinetics of vitamin $c$ degradation in fresh strawberry juices. Procedia Chemistry 9: $62-68$.

${ }^{21]}$ Sudarmadji, Slamet, B. Haryono, dan Suhardi. 2011. Analisa Bahan Makanan dan Pertanian. Liberty. Yogyakarta.

${ }^{22]}$ Fardiaz, Srikandi. 1992. Mikrobiologi Pangan I. Gramedia. Jakarta.

${ }^{23]}$ Soesanto, L. 2006. Penyakit Pascapanen Sebuah Pengantar. Kanisius. Yogyakarta.

${ }^{24]}$ Satuhu, Suyanti. 1996. Penanganan dan Pengolahan Buah. Penebar Swadaya. Jakarta.

${ }^{25]}$ Bodelon, O.G., Blanch, M., SanchezBallesta, M.T., Escribano, M.I., Merodio, C., 2010. The effects of high $\mathrm{CO}_{2}$ levels on anthocyanin composition, antioxidant activity and soluble sugar content of strawberries stored at low non-freezing temperature. Food Chem. 122, 673-678.

${ }^{26]}$ Inggrid, H. Maria, dan Albertus Reynaldi Iskandar. 2016. Pengaruh $p H$ dan temperatur pada ekstraksi antioksidan dan zat warna buah stroberi. Prosiding Seminar Nasional Teknik Kimia "Kejuangan". Yogyakarta.

${ }^{27]}$ Zheng, Y., Wang, C. Y., Wang, S. Y., \& Zheng, W. 2003. Effect of high-oxygen atmospheres on blueberry phenolics, anthocyanins, and antioxidant capacity. J. of Agricultural and Food Chemistry 51: 7162-7169.

${ }^{28}$ Perdones, A., Sánchez-González, L., Chiralt, A., Vargas, M. 2012. Effect of chitosanlemon essential oil coatings onstoragekeeping quality of strawberry. Postharvest Biol. Technol 70: 32-41.

${ }^{29]}$ Ernaini Y, Supriadi A dan Rinto. 2012. Pengaruh jenis pelarut terhadap klorofil dan senyawa fitokimia daun kiambag (Salvinia molesta Mitchell) dari perairan rawa. Fishtech Vol 1(1): 1-13.

${ }^{30]}$ Pantastico, E.R.B. 1997. Fisiologi Pascapanen Penanganan dan Pemanfaatan Buah-buahan dan Sayursayuran Tropika dan Subtrropika. Gadjah Mada University Press. Yogyakarta.

${ }^{31]}$ Apandi, Muchidin. 1984. Teknologi Buah dan Sayur. Alumni. Bandung.

${ }^{32]}$ Ali A, M. Abrar, M. T. Sultan, A. Din And B. Niaz. 2011. Post-Harvest physicochemical changes in full ripe strawberries during cold storage. J. Of Animal \& Plant Sciences, 21(1) : 38-41.

${ }^{331}$ Muchtadi D. 1992. Fisiologi Pasca Panen Sayuran dan Buah-buahan. Pusat Antar Universitas Pangan dan Gizi. IPB. Bogor.

${ }^{34]}$ Purwadi A, W Usada, dan Isyuniarto. 2007. Pengaruh Lama Waktu Ozonisasi Terhadap Umur Simpan Buah Tomat (Lycopersicum esculentum Mill). Prosiding PPI Pustek Akselerator dan Proses Bahan-bahan Yogyakarta.

${ }^{35]}$ Alsuhendra, Ridawati, dan Agus Iman Santoso. 2008. Pengaruh Penggunaan Edible Coating Terhadap Susut Bobot, pH, dan Karakteristik Organoleptik Buah Potong Pada Penyajian Hidangan Dessert. UNJ.

${ }^{36]}$ Aday, Mehmet Seckin, Cengiz Caner, dan Fatih Rahval. 2011. Effect of oxygen and carbon dioxide absorbers on strawberry quality. Postharvest Biology and Technology 62: 179-187.

${ }^{37]}$ Santoso B.B dan B.S. Purwoko. 1995. Fisiologi dan Teknologi Pasca Panen Tanaman Hortikultura. Indonesia Australia University Project, Universitas Mataram. Mataram.

${ }^{38]}$ Mulyawanti, Ira, K. T. Dewandari, dan Yulianingsih. 2008. Pengaruh waktu pembekuan dan penyimpanan terhadap karakteristik irisan buah mangga arumanis beku. J. Pascapanen 5(1): 5158.

${ }^{39]}$ Sahari M. A., Mohsen Boostani F, and Zohreh Hamidi E. 2004. Effect of low temperature on the ascorbic acid content 
and quality characteristic of frozen strawberry. J. Food Chem 86: 357-363.

${ }^{40]}$ Tranggono dan Sutardi. 1990. Biokimia dan Teknologi Pasca Panen. Universitas Gadjah Mada. Yogyakarta.

${ }^{41]}$ Darsana, Linayanti, Endang Setyarini, dan Mey Ary Praptiwi. 2012. Pengaruh Saat Panen dan Suhu Penyimpanan Terhadap Kualitas dan Umur Simpan Buah Anggur (Vitis vinifera L.) Varietas Alphonso Lavalle. UNS.

${ }^{42]}$ Afrianti, Leni Herliani. 2013. Teknologi Pengawetan Pangan. Alfabeta. Bandung.

${ }^{43]}$ Farikha, Ita Noor, Choirul Anam, dan Esti Widowati. 2013. Pengaruh jenis dan konsentrasi bahan penstabil alami terhadap karakteristik fisikokimia sari buah naga merah (Hylocereus polyrhizus) selama penyimpanan. J. Teknosains Pangan 2(1).

${ }^{44]}$ Garcia, M. A., Miriam N. M., dan Noemi E. Z. 1998. Plasticized starch-based coatings to improve strawberry (Fragaria ananassa) quality and stability. J. Agric. Food Chem. 46: 3758-3767.

${ }^{45}$ Sambeganarko, Anggun. 2008. Pengaruh Aplikasi $\mathrm{KmnO}_{4}$, Ethylene Block, Larutan $\mathrm{CaCl}_{2}$ dan $\mathrm{CaO}$ Terhadap Kualitas dan Umur Simpan Pisang (Musa Paradisiaca.L) Varietas Raja Bulu. Skripsi. IPB.

${ }^{46]}$ Winarno, F.G. 2002. Fisiologi Lepas Panen Produk Hortikultura. M-Brio Press. Bogor.

${ }^{47]}$ Amal, Atress A S H. El-Mogy M M, Aboul Anean H E, dan Alsanius B W. 2010. Improving strawberry fruit storability by edible coating as a carrier of thymol or calcium chloride. J. of Horticultural Science and Ornamental Plants 2(3):8897.

${ }^{48]}$ Robertson, GL. 2006. Food packaging principles and practice 2nd edition. Taylor and francis Group LLC. 26-44, 481-483.

${ }^{49]}$ Chempakam, B. 1983. distribution of ascorbic acid oxidase activity in the developing chasew apple (Anacardium occidentale L.). J. Hort. Science 58:447448.
${ }^{50]}$ Winarti, Christina, Miskiyah, dan Widaningrum. 2012. Teknologi produksi dan aplikasi pengemas edible antimikroba berbasis pati. J. Litbang Pert. 31(3): 85-93.

${ }^{51}$ Septiana, Aisyah Tri, Deddy Muchtadi, dan Fransiska R. Zakaria. 2002. Aktivitas antioksidan ekstrak dikholorometana dan air jahe (Zingiber officinale Roscoe) pada asam linoleat. J. Teknologi dan Industri Pangan 8(2): 105-110.

${ }^{52]}$ Robinson, T. 1995. Kandungan Organik Tumbuhan Tinggi. ITB Press. Bandung.

${ }^{53]}$ Syarief, Rizal, Sassy Santausa, St. Isyana B. 1989. Teknologi Pengemasan Pangan. Laboratorium Rekayasa Proses Pangan Pusat Antar Universitas Pangan dan Gizi IPB. Bogor.

${ }^{54]}$ Astawan, Made. 2008. Sehat Dengan Buah. Dian Rakyat. Bogor.

${ }^{55]}$ Jagetia GC, Baliga MS, Venkatesh P, Ulloor $\mathrm{J}$. 2003. Influence ofginger rhizome (Zingiber Officinale Rosc.) on survival, glutathione and lipid peroxidation in mice after whole-body exposure to gamma radiation. Radiat Res, 160: 584-592.

${ }^{566}$ Rialita, Tita, Winiati Pudji Rahayu, Lilis Nuraida, Budi Nurtama. 2015. Aktivitas antimikroba minyak esensial jahe merah (Zingiber Officinale Var. Rubrum) dan Lengkuas Merah (Alpinia Purpurata K. Schum) terhadap bakteri patogen dan perusak pangan. Agritech 35(1).

${ }^{57}$ Ellis MA, Erincik O. 2008. Anthracnose Of Strawberry Fact Sheet. The Ohio State University.

${ }^{58]}$ Syahputra, Ade, Nurul Dwi Handayani, Indriani Kusumawati Daud Malvini. 2012. Etil format sebagai perlakuan alternatif terhadap Colletotrichum gloeosporioides pada stroberi. Jurnal Fitopatologi Indonesia 8(6): 177-183.

${ }^{59]}$ Zhang, H., Wang, L., Dong, Y., Jiang, S., Cao, J., \& Meng, R. 2007. Postharvest biological control of gray mold decay of strawberry with rhodotorula glutinis. Biological Control, 40, 287-292. 